\title{
TITLE:
}

\section{TWO NEW AMPHIPODS OF THE GENUS EURYSTHEUS FROM JAPAN}

AUTHOR(S):

Nagata, Kizo

\section{CITATION:}

Nagata, Kizo. TWO NEW AMPHIPODS OF THE GENUS EURYSTHEUS FROM JAPAN. PUBLICATIONS OF THE SETO MARINE BIOLOGICAL LABORATORY 1961, 9(1): 31-36

ISSUE DATE:

1961-05-30

URL:

http://hdl.handle.net/2433/174664

RIGHT: 


\title{
TWO NEW AMPHPODS OF THE GENUS EURYSTHEUS FROM JAPAN
}

\author{
Kızô NAGATA \\ Inland Sea Regional Fisheries Research Laboratory
}

With 2 Text-figures

No species belonging to the genus Eurystheus of the gammaridean amphipods has hitherto been recorded from the coast of Japan. In the neighbouring water of Japan, however, the only one species E. sexdentata is known from Liato Peninsula on the Chinese coast (Stephensen, 1944, p. 72, figs. 26, 27). Among the family Photidae the genus Eurystheus closely resembles the genera Megamphopus and Podoceropsis, but differs in having the epistomal spine of upper lip, and usually the multiarticulate accessory flagellum of antenna 1 . This genus seems to have rather many species closely resembling one another as enumerated up to fifty-four in number of its valid species in J. L. BARNARD's "Index of the gammaridean Amphipoda" (1958, p. 112). K. H. BARNARD says in Discovery Reports (1932, p. 224) "There seems to be a never-ending influx of forms in this genus as each fresh expedition brings home its captures. Undoubtedly the simplest way to deal with these forms is to give specific names to each, rather than to assume local variability on the part of one and the same 'species'." In truth, the writer always thinks it wise to creat a distinct species rather than to identify with the known species with hesitation and to result in leading to the error on the point of its geographical distribution, particularly so on the most interesting and frustrating group, until a program on the study of its life history or its multiform is effected.

E. utinomii n. sp. which is described for the first time in the present paper is so far known to occur only in the Seto Inland Sea, and often abundantly appears in the stomach contents of fishes catched there. Another new species E. japonicus to be described herein is, though much variable, widely distributed all along the coast of Japan, northerly from Asamushi (Mutsu Bay) southerly to the west coast of Kyûshu, and Nakaumi (Shimane Prefecture).

I wish to express my hearty thanks to the following persons: Dr. T. HANAOKa of the chief of our laboratory for his critical reading of the manuscript; Dr. $\mathrm{H}$. UTINOMI of Seto Marine Biological Laboratory, Kyoto University for many valuable

Publ. Seto Mar. Biol. Lab., IX (1), 1961. (Article 3) 
advices; particularly to Mr. H. SANDô of Tôhoku University, and Mr. T. KIKUCHI of Kyûshu University, for sending the useful materials for this study.

\section{Eurystheus japonicus n. sp.}

(Fig. 1)

Male-Pleon segments 4 and 5 armed with two minute medio-dorsal teeth on the hind margin, together with a seta at the base of each lateral tooth. Head, lateral lobes lobate, not pointed apically. Side plate 2 the largest and the deepest. Pleon segment 3 , lower hind corner with an acute tooth, margin above bulging, then nearly straight. Eyes long oval, reniform and dark. Accessory flagellum of antenna 1 five-seven jointed. Upper lip with epistome produced acutely and right-angularly in front. Gnathopod 1, article 5 slightly longer than article 6; palm ill-defined; finger denticulate. Gnathopod 2 larger and powerful ; articles 2 and 5 robust and subequal; the anterodistal corners of article 2 lobate; article 6 nearly equal to or slightly longer than article 5 ; palm oblique with three denticles or tubercles of which the middle one in specimens from Seto Inland Sea is the largest and projecting across the finger, whereas the appearence of these denticles in Asamushi specimens, rather resemble those of SARs' figures of E. maculatus (1895, pl. 198); hind margin of article 6 sometimes shorter than palm, sometimes longer, and nearly parallel with its anterior margin. Peraeopods 3-5 with articles 2 and 4 much variable in shape and the hind margin slightly serrated; peraeopod 4 longer than or subequal to peraeopod 5 ; peraeopod 3 , article 2 well expanded and broadened distally, article 4 more or less widened; peraeopod 4, article 2 well expanded or rather narrow, and its hind margin convex or slightly concave, article 4 less widened; peraeopod 5, article 2 more or less narrowing distally, article 4 normal. The other points typical without any characteristics.

Female-Differing from the male only in peraeon segment 2 and its coxal plate, gnathopod 2, and peraeopods 3-4. The breadth of peraeon segment 2 and the depth of its coxal plate normal. Gnathopod 2 not powerful and not variable; article 2 rather slender; article 5 much shorter than article 6 of which palm with two denticles, widely concave between the two, and bearing a rather strong spine near the defined denticle. Peraeopods 3-5 not variable; article 2 of peraeopod 3 moderately broadened, and those of peraeopods $4-5$ narrowing distally; the shapes of article 2 of peraeopods 3-5 in Asamushi specimens are, however, somewhat different from those of specimens from Seto Inland Sea in the longer and more slender shape to their width.

Type locality-St. 1, Hosonosu, Hiroshima Pref., Seto Inland Sea, Dec. 12, 1956. Holotype, male $8 \mathrm{~mm}$ (figured), No. 2055; Allotype, ovig. female $6 \mathrm{~mm}$ (figured), No. 2089, and 2 paratypes, all preserved now in my hand.

Occurrence-Seto Inland Sea: Hosonosu, 11 specimens; Mihara Bay, 10 spec. 


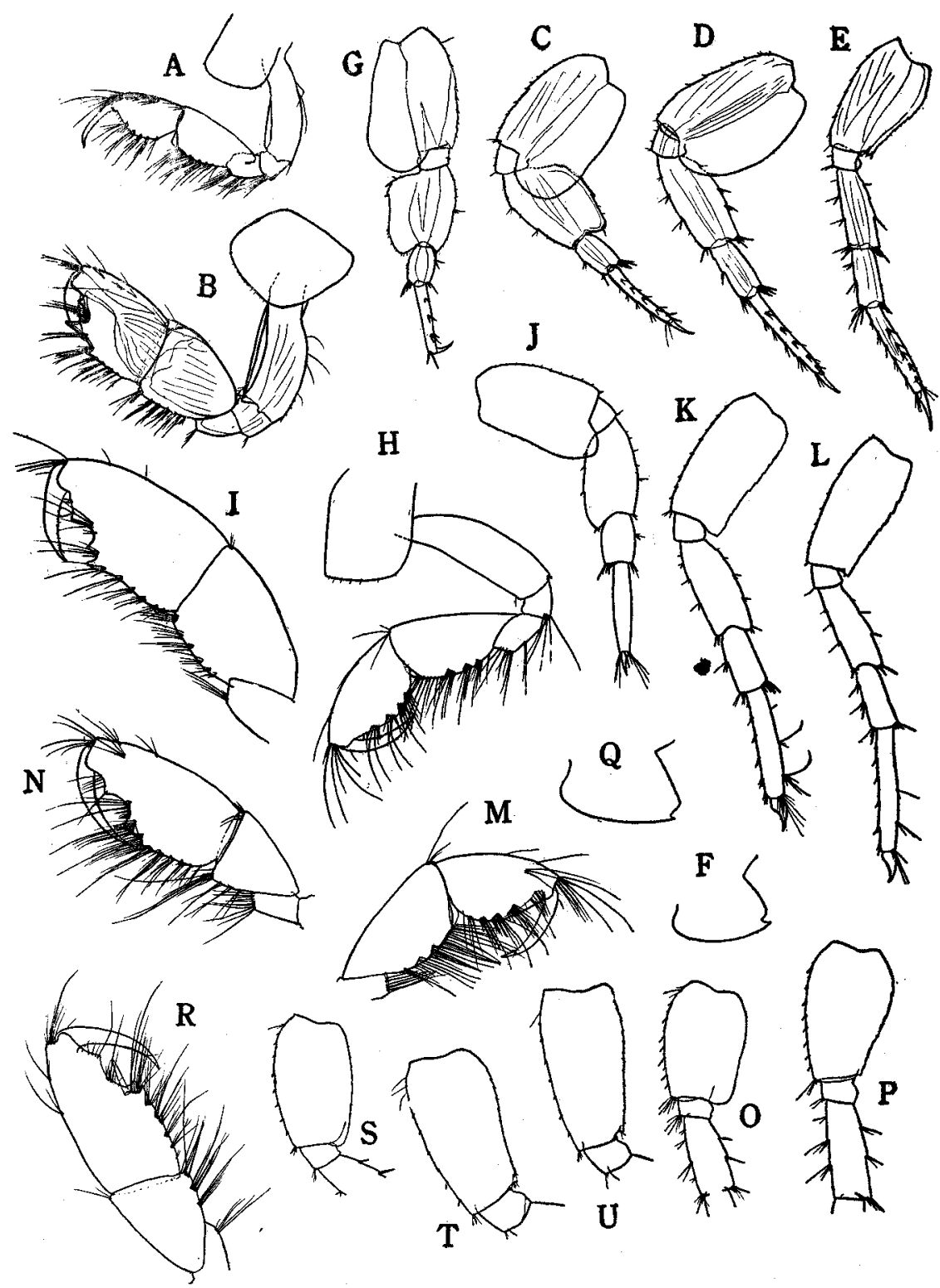

Fig. 1. Eurystheus japonicus n. sp., Seto Inland Sea: male, $8 \mathrm{~mm}$., A and B-gnathopods 1 and 2, C to E-peraeopods 3-5, F-epimeral plate 3 ; male $5.8 \mathrm{~mm}$., G-peraeopod 3 ; ovig. female, $6 \mathrm{~mm}$., $\mathrm{M}$ and $\mathrm{N}$-gnathopods 1 and $2, \mathrm{O}$ and $\mathrm{P}$-peraeopods 3 and 4, Q-epimeral plate 3: Mutsu Bay: male, $5 \mathrm{~mm}$., $\mathrm{H}$ and I-gnathopods 1 and 2, J-to L-peraeopods $3-5$; ovig. female, $4.5 \mathrm{~mm}$., R-gnathopod $2, \mathrm{~S}$ to Uperaeopods $3-5$. Peraeopods $3-5$ the same proportion of enlargement in each specimen. 
Asamushi, Mutsu Bay, northern Japan, 74 spec., coll. Mr. H. Sandô. Tomioka Bay, the west of Kyûshu, 1 spec., and Nakaumi, Shimane Pref., 6 spec. from the stomachs of fishes, both coll. Mr. T. KIKUсHI.

Remarks-This species is much closely related to the type E. maculatus and E. thompsoni, particularly in the structure of male gnathopod 2, but differs from the former in the color of eyes, the shape of epimeral plate 3 , having two small medio-dorsal teeth also on pleon segment 5, and the shape of article 2 of peraeopods 3-5; from the latter (WALKer 1898, p. 283, pl. 16, figs. 3-6 ; Shoemaker 1942 , p. 28 , fig. 10 , as the name of tenuicornis and its var. lobata), in the deepest side plate 2, rather different shape of epimeral plate 3 , and much broadened articles 2 and 4 of male peraeopods 3-4. Both maculatus and thompsoni are not likely to be described at all on such a remarkable difference in sexes on peraeopods 3-5. The writer, however, remembers a certain coincidence with only a male specimen reported by Chilton under the name of maculatus from the Australian Sea (1921, p. 80, fig. 12) in which articles 2 and 4 of peraeopod 5 (3?) are somewhat broadened in shape. These all curious specimens at hand, might be said to be an intermediate form between maculatus and thompsoni. Asamushi specimens are the same form as the specimens from both Tomioka Bay and Nakaumi, and seem to be a variety of the specimens from the type locality and herein described and figured together.

\section{Eurystheus utinomii n. sp.}

(Fig. 2)

Male-Medio-dorsal teeth of pleon segments 4 and 5 , the largest and the deepest side plate 2, eyes, and antennae, are all as in the preceding species. Head, lateral lobes lobate, but minutely pointed at apex. Lower hind corner of pleon segment 3 with a minute tooth, bulging above, its hind margin convex. The other oral parts are proper for this genus and without any characteristics. Side plate 1 with lower hind margin dentate. All legs rather slender than those of the preceding species. Gnathopod 1, article 5 longer than article 6 of which palm ill-defined. Gnathopod 2 strongly developed and the right and left legs usually crossing each other under the body; article 2 powerful; articles 5 and 6 much elongate, club-shaped, thickly grown up, and subequal in length; palm indistinct, being in a straight line with the hind margin, and having no tubercles; posterior margin of articles 5 and 6 heavily bristled; article 7 rather stout and short, and having many blunt teeth along the inner margin. Peraeopods 3-5 successively longer; peraeopods 4 and 5 with article 2 well expanded, particularly that of peraeopod 5 much expanded, triangular or subquadrate in shape, its anterior margin bearing two large teeth, near the points attached to side plate with a triangular tooth, and the hind margin roughly dentate Uropods and telson normal as in the type. 
Female-Distinguished from the male by the following points: Gnathopod 2 rather slender; palm of article 6 short, but distinctly visible. Peraeopods 3-5. article 2 not much expanded; article 4 normal in width.

Type locality-St. 6, $10 \mathrm{~m}$ in depth, below low tide marks of Mihara Bay. June 15, 1956. Holoty pe, male $7.5 \mathrm{~mm}$ (figured), No. 2029; Allotype, oviger. female $6.5 \mathrm{~mm}$ (figured), No. 2257, and 19 paratypes, all preserved now in my hand.

Occurrence-Seto Inland Sea: Mihara Bay, St. 5 (4 spec.), 6 (332), 7 (412), 8 (954), between Feb. 1956 and Aug. 1956; many specimens from the stomachs of fishes.

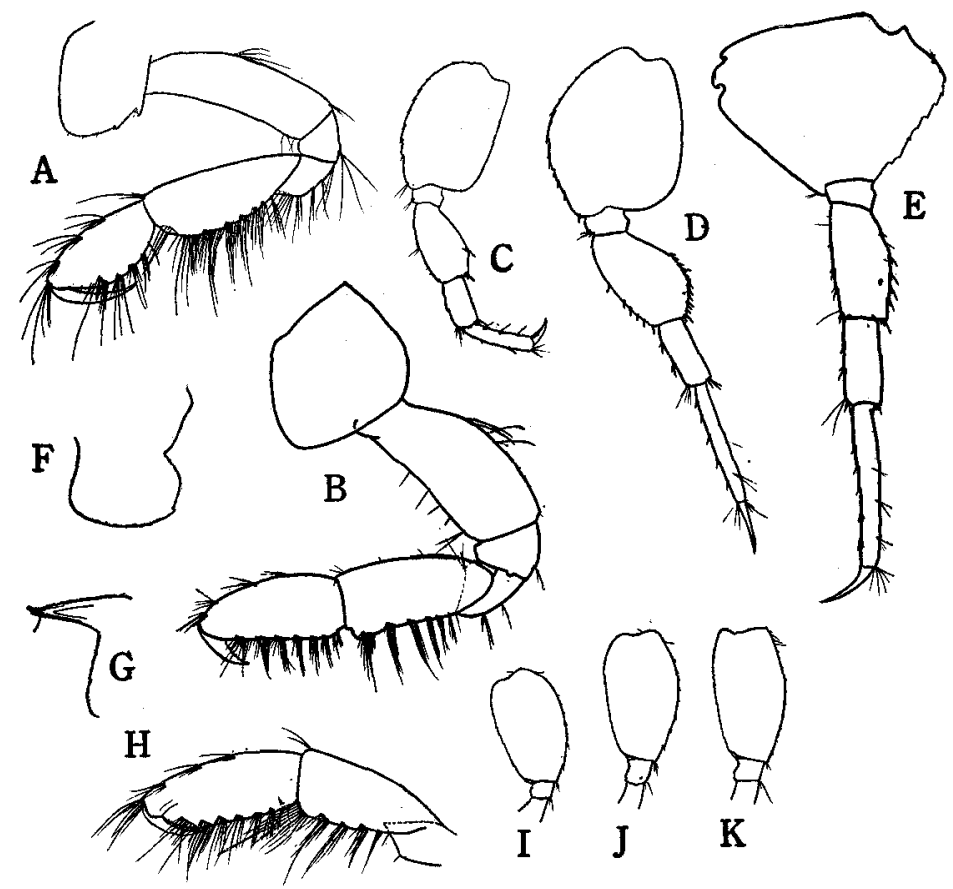

Fig. 2. Eurystheus utinomii n. sp., male, $7.5 \mathrm{~mm}$., A and B-gnathopods 1 and 2, $\mathrm{C}$ to $\mathrm{E}$-peraeopods 3-5, F-epimeral plate $3, \mathrm{G}$-epistomal spine; ovig. female, $6.5 \mathrm{~mm}$., $\mathrm{H}$-gnathopod 2 , I to $\mathrm{K}$-peraeopods 3-5. Peraeopods 3-5 the same proportion of enlargement in each specimen.

Remarks-This species can be easily recognized by the unique characteristics of male gnathopod 2 and the shape of article 2 of male peraeopod 5 . The writer knows of no other species in this genus having such a remarkable one, except E. longicarpus REID (1951, p. 259, fig. 50) which has a rather similar structure of male gnathopod 2. Differing from the latter, in the shape of eye, the deepest side plate 2, rather different shape of epimeral plate 3 , much more elongated, club-shaped articles 5 and 6 of male gnathopod 2, its palm having no prominences, and the shape of article 2 of peraeopod 5. It gives me a great pleasure to name this characteristic new species after Dr. H. UTINomi. 


\section{LITERATURE}

BARNARD, J. L., 1958: Index to the families, genera, and species of the gammaridean Amphipoda. Allan Hancock Found. Publ., Occ. Pap., No. 19.

BARNARD, K. H., 1932: Amphipoda. Discovery Reports, Vol. 5.

ChIl TON, C., 1921 : Report on the Amphipoda obtained by the F. I. S. "Endeavour" in Australian Sea. Biol. Res. "Endeavour", Vol. 5, No. 2.

REID, D. M., 1951: Report on the Amphipoda (Gammaridea and Caprellidea) of the coast of tropical west Africa. Atlantide Rpt., Vol. 2.

SARS, G. O., 1895: Amphipoda. An account of the Crustacea of Norway, Vol. 1.

SHoEmaKer, C. R., 1942: Amphipod crustaceans collected on the presidental cruise of 1938. Smithsonian Misc. Coll., 101, No. 11.

Stephensen, K., 1944 : Some Japanese amphipods. Vid. Medd. fra Dansk, Naturh. Foren., Bind 107.

WAlker, A. O., 1898: Crustacea collected by W. A. Herdman, F. L. S., in Puget Sound, Pacific coast of North America, Sept. 1897. Proc. Trans. Liverpool Biol. Soc., Vol. 12. 